\title{
FINANCIAL \\ INTEGRATION \\ AND THE GREAT \\ LEVERAGING
}

Working Papers 2014

\author{
Daniel Carvalho
}

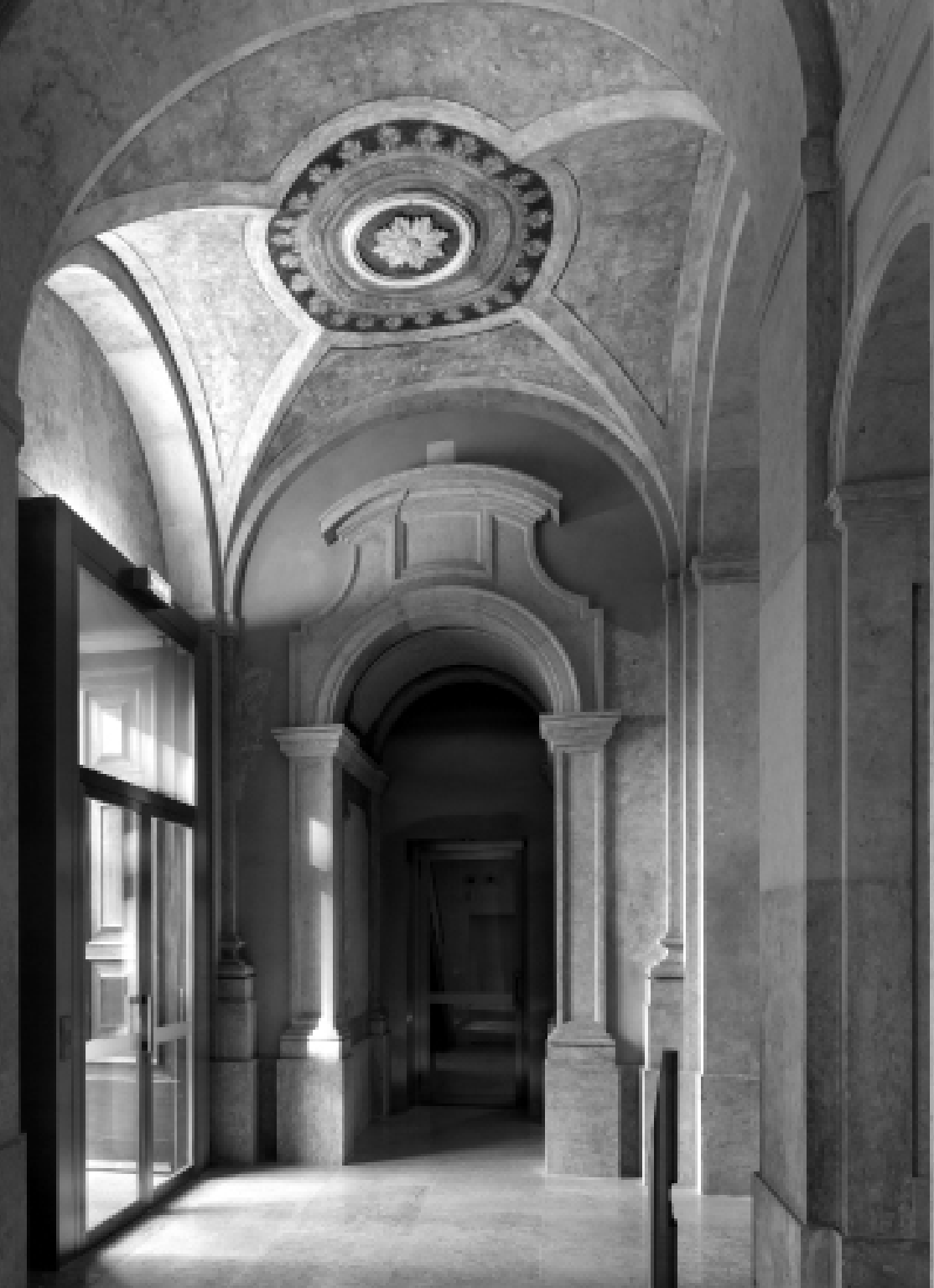





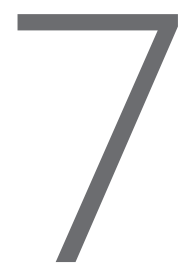

\section{FINANCIAL INTEGRATION AND THE GREAT LEVERAGING}

Working Papers 2014

Daniel Carvalho

March 2014

The analyses, opinions and findings of these papers represent the views of the authors, they are not necessarily those of the Banco de Portugal or the Eurosystem

Please address correspondence to

Banco de Portugal, Economics and Research Department

Av. Almirante Reis 71, 1150-012 Lisboa, Portugal

Tel.: 35121313 0000, email: estudos@bportugal.pt

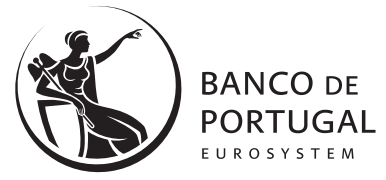

Lisbon, 2014 - www.bportugal.pt 
WORKING PAPERS | Lisbon 2014 • Banco de Portugal • Av. Almirante Reis, 71 | 1150-012 Lisboa • www.bportugal.pt • Edition Economics and Research Department • ISBN 978-989-678-285-6 (online) • ISSN 2182-0422 (online) • Legal Deposit no. $3664 / 83$. 


\title{
Financial integration and the Great Leveraging
}

\author{
Daniel Carvalho*
}

March 8, 2014

\begin{abstract}
This paper studies how international capital flows affect domestic credit and money holdings. While previous studies have focused on credit growth and highlighted the importance of the equity/debt mix of flows, this paper shows that there are also important implications of flows going to different domestic recipient sectors, especially concerning money dynamics. In particular, crossborder banking flows display a strong comovement with credit but none with broad money; in turn, flows of domestic non-banks display comovement with both credit and money. For this reason, banking flows correlate with the decoupling of these two variables - the Great Leveraging -, a stylised fact documented for several economies in the past decades and associated to the rapid expansion of banks non-monetary liabilities. These results thus shed light on the mechanisms through which the international banking activity might have consequences for the composition of the domestic bank balance sheet.
\end{abstract}

JEL No.: E44, F30, G15.

Keywords: Capital flows, money and credit.

\footnotetext{
*Banco de Portugal, Rua Francisco Ribeiro 2, 1150-165 Lisboa, Portugal, daniel.sousa.carvalho@bportugal.pt. I am grateful to Philip Lane for invaluable discussions and comments. I would also like to thank macro working group participants at Trinity College Dublin for comments. The opinions expressed in this paper represent the views of the author, they are not necessarily those of the Banco de Portugal, the European Central Bank, or the Eurosystem.
} 


\section{Introduction}

A number of studies have shown that episodes of rapid credit expansions are important in understanding the emergence of crises as well as their magnitude. For instance, Mendonza and Terrones (2008) propose a method to identify credit booms and use it to show that, in both advanced and emerging economies, the build up of credit booms contributes to expansions, raising asset prices, appreciation and external deficits; in turn, the bust phase is associated with the opposite dynamics. Jordà et al. (2012) show that this is not a feature circumscript to recent times and modern economies, it is something common to different eras in the historical dataset they build going back all the way to 1890. However, it is a feature specific to credit provided to the private sector: whereas private debt contributes to elevated financial crisis risks, a country's fiscal position becomes important only once a crisis has already erupted (see Jordà et al. 2013).

With the same historical perspective, Schularick and Taylor (2012) observe that there are two periods concerning the dynamics of credit and money. They describe that money and credit were growing at roughly the same pace since the end of the Second World War until the early 1970s, but from that period on credit grew faster than money. This decoupling between both variables - labeled the Great Leveraging by Taylor (2012) -, was achieved by the fast expansion of banks non-monetary liabilities, such as long-term debt securities, which enabled them to grant credit beyond their deposit base, and can be seen as a measure of leverage in the banking sector. Furthermore, based on the crisis classifications in Bordo et al. (2001), they provide the link between faster credit growth and crises, by noting that the decoupling between credit and money went hand in hand with a resurgence of these

episodes since the 70s; however, there were barely any crisis episodes before that. Moreover, they show that credit is a predictor of crises while money is not. Their intuition for this result is that credit is a more encompassing measure of bank balance sheets as it captures features such as leverage and non-monetary liabilities which money doesn't.

In turn, Baeriswyl and Ganarin (2011) see the decoupling between credit and money as an opportunity to empirically test which of the two variables drives aggregate demand and inflation and thus solve the decade long dispute between the "credit view" and the "money view". With a focus on 
the United States and Switzerland, they conclude that money is the relevant variable to explain inflation, corroborating Friedman's (1970) assessment that "inflation is always and everywhere a monetary phenomenon". Putting the pieces together, while the asset side of bank balance sheet is the relevant one for financial stability purposes, the liability side is the relevant for monetary policy and price developments. A direct consequence of the latter is that the decoupling between credit and money has important implications for the role of central banking: when both variables were growing in tandem, by setting interest rates and controlling money growth, central banks were also determining developments in credit. Hence, with only a weak relationship between both variables, targeting inflation might be insufficient to address undesirable credit expansions.

International capital flows and financial integration have commonly been associated with periods of rapid credit growth and the likelihood of crisis. For instance, Reinhart and Reinhart (2008) examine the links between capital flows and financial crises and draw unconditional probabilities of a crisis given episodes of capital flow bonanzas. Against the backdrop of the financial crisis, Lane and MilesiFerretti (2012) study the process of external adjustment and conclude that countries with higher current account deficits in the pre-crisis period than would be explained by underlying economic fundamentals experienced sharper corrections once the crisis erupted. Still, these studies do not capture the mechanisms through which the cross-border financial activity might contribute to credit growth and ultimately to crisis events.

In a more recent contribution, Lane and McQuade (2013) explore directly the relation between private credit growth and different types of international capital flows. In a cross-country set up including the 27 European Union countries together with Norway, Switzerland and Iceland, they show that while debt flows exhibit a strong co-variation pattern with private domestic credit growth, equity flows do not play a significant role. Hence, looking only at aggregate net measures of capital flows such as the current account might be misleading.

The central question of this paper is to assess how financial integration and specifically how different types of capital flows can help explain developments in the relationship between credit and money. Despite the examples of studies where the relationship between cross-border finance and private domestic credit is analysed, the literature is yet to explore how financial integration affects the interplay 
between credit and money. Looking at both variables in the same framework puts together the asset and liability sides of the banking sector balance sheet in an integrated manner. It casts light on how cross-border capital flows contribute to the funding of domestic banks and how they might affect the shape and composition of liabilities and finally link it to the asset side and the transmission of this funding into domestic credit to non-banks.

A key element of international capital flows which needs to be taken into consideration in this context is the sectoral composition. Why is the sectoral composition relevant? The access to international capital markets should influence credit growth as it increases the pool of resources available to banks. In this sense, cross-border capital inflows to all sectors should be conducive to an increase in domestic credit. Moreover, cross-border flows should influence the level of domestic money holdings. However, it is not clear ex-ante that cross-border capital flows of different sectors should necessarily influence domestic money in the same fashion. To the extent that a significant share of the cross-border banking activity involved less liquid instruments of a non-monetary nature, this raises the question of whether there might be different implications to domestic money holdings of international capital flows to banks and non-banks since bank flows might expand the resources they have available to provide domestic credit without increasing their monetary liabilities. Under this scenario, banking flows could be conducive to the decoupling between both variables. To analyse this question, I rely on the monetary presentation of the balance of payments which, in a nutshell, establishes a statistical link between balance of payments flows and monetary aggregates, thus enabling to track how cross-border capital flows affect domestic money holdings.

Results show that banking sector flows are indeed the relevant ones to explain the decoupling of credit and money for a group of countries encompassing OECD members plus other mostly Asian and Latin American: banking flows display a strong co-variation with credit growth dynamics while at the same time they are not significant at explaining developments in money. In fact, it turns out that money growth is exclusively associated with non-banking sector flows, while the relation of these flows with credit is less pronounced than with those of banks. Furthermore, in terms of the equity/debt split, these results also corroborate those of Lane and McQuade (2013) in the sense that most of these relationships work via debt flows while equity mostly plays only a negligent role. 
The rest of the paper is organized as follows: Section 2 discusses the relationship between money, credit and international capital flows, with an emphasis on the monetary presentation of the balance of payments; Section 3 goes through the data and stylised facts; Section 4 introduces the empirical approach and the results obtained; concluding remarks are provided in Section 5.

\section{Money, credit and international capital flows}

A natural way to approach the relationship between money and international capital flows is to recall the concept of the monetary presentation of the balance of payments. This particular idea hasn't received much attention in the literature in recent times, most theoretical contributions already have a few decades. For instance, Johnson (1972) surveys monetary balance of payments models which, in contrast to Keynesian models that focus on relative price changes, look at the direct impact of the demand and supply for money on the balance between income and expenditure. He concludes that monetary balance of payments models are better suited for policy guidance in the long-run since they assume full employment of resources and that domestic price levels are in line with international price levels (Polak (2001) discusses in detail the Keynesian and the Johnsonian monetary approaches to the balance of payments). Along the same lines, Kemp (1975) argues that the balance of payments embodies an automatic adjustment mechanism, whereby divergences between actual and desired money balances are corrected. Importantly, no distinction is made between the different items of the balance of payments; the only thing that this class of models states is that excess supply or demand for money will be cleared in the goods, services or securities markets.

Both papers focus on how money demand and supply affect the current account balance and/or cross-border capital flows. More recent contributions instead look at how cross-border flows affect money aggregates, which is the adequate approach for the purpose of this paper. The ECB looks regularly publishes the monetary presentation of the euro area balance of payments together with its monthly releases and uses it in its regular analysis of monetary aggregates' development: 1 . One useful way to think about how cross-border flows may have a direct influence on the domestic money

\footnotetext{
${ }^{1}$ see for instance ECB (2008) as well the regular box on financial flows in the quarterly editions of the ECB's Monthly Bulletin
} 
stock is to split them into transactions between non-residents and domestic (i) MFIs or money-issuing sectors and (ii) non-MFIs or the money-holding sectors. The monetary presentation of the balance of payments concentrates on the latter.

To see how transactions of the money-holding sectors might influence money dynamics, it is best to first look at the components of money. While in practice, it is up to each country to define its own money aggregates $2^{2}$ it is nevertheless possible to define a general broad money concept using the consolidated aggregate balance sheet of the resident MFIs, i.e., the sum of all individual MFI (including the central bank) balance sheets after netting out intra-MFI positions, as depicted in Figure 1 .

Money aggregates are typically expressed on the basis of the liability side of the balance sheet. Accordingly, broad money can be defined as generally consisting of currency in circulation, liquid deposits and other instruments with a given level of liquidity, such as repurchase agreements, debt securities (normally with a maturity below two years) and money market fund shares. Not included in money aggregates are other longer-term liabilities such as deposits with an agreed maturity and those redeemable at a period of over three months, as well as capital, reserves and provisions and other liabilities, such as central government deposits.

But, given that, by construction, the asset and liability sides of the aggregate consolidated balance sheet of the MFI sector must add up to the same amount, one can also define money aggregates using the asset side components or counterparts of money, which are more illustrative of the money creation mechanism. With this second approach, broad money $(\mathrm{M})$ can be defined as the sum of domestic credit to non-banks (DC), net external assets (NEA) obtained as the difference between claims on and liabilities to non-residents, and other domestic assets such as securities issued by domestic residents minus longer-term financial liabilities as defined before:

$$
M=D C+N E A+O D A-L T F L
$$

Changes to the broad money stock can then be traced to changes to domestic credit, net external transactions of the money issuing sector (NETMI) and net other domestic transactions (NODT):

\footnotetext{
${ }^{2} \S 283$ of the IMF's Monetary and Financial Statistics Manual states that "this manual does not contain prescriptions for national definitions of money, credit and debt, which are left to the discretion of national authorities"
} 


$$
\Delta M=\Delta D C+N E T M I+N O D T
$$

The next step is to establish a relation between net external transactions of banks and balance of payments flows. Since MFI balance sheet and balance of payments statistics follow similar concepts, transactions in both sets of statistics are equivalent ${ }^{3}$ This means that using balance of payments cross-border banking flows instead of the ones derived in MFI balance sheet data is appropriate in this context. But then, given that, by construction, balance of payments flows must sum to zero, it is trivial to realise that the net external transactions of the money-issuing sectors must be symmetrical to those of the money-holding sectors (NETMH), i.e., NETMI+NETMH $=0$ or $N E T M I=-N E T M H$. Combining both expressions, we get

$$
\Delta M=\Delta D C-N E T M H+N O D T
$$

which finally establishes a direct relationship between broad money and non-bank balance of payments flows. Thus, in a nutshell, constructing the monetary presentation of the balance of payments involves isolating the balance of payments items that mirror the net external transactions of non-MFIs, which have an effect on the net external assets of banks and finally money holdings.

To better understand, consider the following example: if a domestic household sells an asset to another domestic household, there is no change in money holdings in the economy. In contrast, consider the case of a domestic household who sells an asset to a foreign resident: if the buyer uses a foreign account to pay for the asset and the domestic household deposits the proceeds in a domestic bank account, then money holdings will increase.

Importantly, this refers only to the direct effect of the capital flow on the MFI balance sheet. Other second round effects may follow suit. Using the same example as before, if the domestic MFI where the deposit is held then decides to use the extra money to increase loans to the domestic sector, this will lead to a further expansion of the aggregate balance sheet, if the funds are subsequently deposited and lent domestically. The size of the balance sheet expansion (or, in other words, money creation)

\footnotetext{
${ }^{3}$ There might be some differences in practice because of different compilation methods but those are deemed to be relatively small
} 
will ultimately depend on the money multiplier.

However, in some situations the size of the aggregate balance sheet may remain unchanged. This would be the case if, considering the converse of the previous example, a resident household finances the purchase of foreign securities with a loan instead of drawing down its deposit, this will not reduce the money holdings in the domestic economy.

Furthermore, although both sets of statistics have similar concepts, in practice, however, there may be divergences. The most important is the underlying assumption in the above reasoning, that the resident banking sector is involved in these money-holding sectors transactions. Going back to the previous example, if the resident household uses a non-resident bank account to purchase a foreign asset, this does not have an impact on the country's money stock; nevertheless, it should still be recorded in the balance of payments as it represents a financial transaction between a resident and a non-resident counterpart 4

Finally, the last remaining link that needs to be established is between the standard detail provided in balance of payments statistics and the money-issuing and -holding sectors flows. In broad terms, it (almost exclusively) involves using the sectoral breakdown available in the financial account; a more detailed description is provided in the data appendix.

In itself, the monetary presentation of the balance of payments provides information on patterns and dynamics of financial account flows which allow for two main interesting analysis. On the one hand, they allow understanding which specific types of capital and/or instruments are being purchased or sold and, to the extent that they have different characteristics, the respective impacts and implications of these operations in money developments. In broad terms, the details available in the financial account are on (i) functional categories - foreign direct investment, portfolio investment, other investment -, the financial instrument - securities, loans, deposits, etc. - and the type of capital - equity or debt. On the other hand, the monetary presentation of the balance of payments provides not only measures of net but also gross flows, i.e., asset and liability flows. Specifically, domestic money holdings might change because of the behaviour of both resident and non-resident investors. For instance, money holdings might increase (decrease) because domestic residents sell (buy) foreign assets or because

\footnotetext{
${ }^{4}$ In practice, this situation should be mitigated by the fact that these are typically the transactions which statisticians have the greater difficulties to record. This is because normally the resident banking sector is the basis of reporting.
} 
foreign investors buy (sell) domestic assets (or both, of course). Understanding the origin of flows that affect money holdings could also be analytically relevant $t^{5}$ In short, the monetary presentation of the balance of payments enables (i) linking developments in money aggregates to cross-border transactions in specific asset classes and (ii) disentangling domestic versus foreign residents behaviour by looking separately at the dynamics of assets and liabilities.

\section{Data and stylised facts}

In this section I briefly describe the data I use. More detailed information is provided in the data appendix. The list of countries covered and the time periods are in Table 3 . Although data for Luxembourg are available, I make the standard assumption and remove it from the analysis due to the significant mutual fund industry operating from the country ${ }^{6}$.

\subsection{Data}

Starting with credit, I follow Lane and McQuade (2013) and use the private credit to the private nonbank sectors by banks published by the IMF in the International Financial Statistics (IFS) dataset. The BIS staff has recently put together a new credit dataset for some fourty countries (details are provided in Dembiermont et al. 2013). In broad terms, this new dataset differs from the IFS credit series (or any other typical credit measure) in two main aspects: (i) it includes cross-border credit directly to domestic non-banks and (ii) credit provided by domestic non-banks. There are two reasons for not considering these credit series and sticking to those of the IFS. The first is a conceptual reason: the focus of this paper is on the aggregate balance sheet of MFIs, i.e., how international capital flows directly affect its asset side (credit) and its liability side (money holdings). The two additional sources of credit contemplated in the new BIS series bypass the domestic banking sector and are therefore not consistent with the paper's goal. The second reason is of a practical nature: the country coverage

\footnotetext{
${ }^{5}$ For instance, Forbes and Warnock (2012) show the importance of using gross flows and clearly disentangling the behaviour of domestic and foreign investors when assessing episodes of capital surges and stops

${ }^{6}$ The cross-border capital flows associated with the mutual funds industry are typically (i) very large and have a very limited impact in the domestic economy and (ii) imbalanced in the sense that equity flows associated to purchases of mutual fund shares are recorded on the liability side while debt flows are recorded on the asset side on account of the large bond portfolios these funds hold.
} 
in these new BIS series is smaller and, intersected with the capital flows data availability, would significantly reduce the number of countries considered.

Turning to money series, these are also from the IFS dataset and are broad money aggregates (mostly M3 but also M2 and other broad measures whenever M3 is not available). Additionaly, one particular case is that of euro area countries, for which individual national money aggregates are not available. National contributions to the euro area money aggregates are available from the ECB but these are based on an euro area wide residency concept, i.e., they exclude intra-euro area banking positions. Using these as measures of national money aggregates would therefore likely hamper the analysis since the share of intra-euro area positions among total banking positions is significant for most EMU countries - Spiegel $(2009 a, b)$ for instance discusses the increase and the drivers of euro area countries share in the total borrowing of Portuguese and Greek banks. Moreover, using a euro area wide residency concept would also be inconsistent with the residency concept underlying the national balance of payments flow data of individual euro area countries. For these reasons, I computed proxies for these aggregates using IFS data, which are based on the relevant national residency concept. More details can be found in a dedicated subsection in the data appendix. Table 4 displays the complete list of the aggregates I used for each country.

Finally, concerning capital flows data, the source is the IFM balance of payments database. I focus on net measures of debt and equity flows, both for the money-issuing and holdings sectors. A positive figure represents net capital inflows whereas a negative figure represents net outflows. Details on the construction of these measures are provided in the respective section of the data appendix. I also consider the current account balance for completeness. To get a better feel for these capital flows measures, Table 5 displays correlations between net equity and debt flows of money-issuing and -holding sectors with the change in the BIS net external bank claims for the available countries (all scaled by GDP and in the 1999-2007 period). The latter measure is a proxy for cross-border bank flows as changes in net claims, although also reflecting price and exchange rate variations, are mostly related to flows. As can be seen and despite these limitations, the correlation of the net debt flows of the money-issuing sectors with the BIS measure is particularly strong and positive, as expected. 


\subsection{Some stylised facts}

I start by focusing on annual data for the 1999-2007 period. There are two reasons for choosing this period. First, given that 1999 is the initial data point for the euro area countries' money aggregates proxies, I use this year as starting point so as not mix the previous national monetary aggregates with these proxie: 7 Moreover, going further back than 1999 would also reduce the country coverage due to data availability. Second, I intentionally exclude the crisis period, as Lane and McQuade (2013) also do.

Table 6 displays some basic descriptive statistics for the countries in the dataset. Starting with the total, we see that credit and money scaled by GDP are almost identical, thus leading to a ratio of these variables of almost one. Moreover, this ratio was increasing in the period under consideration as credit grew faster than money. However, the statistics for the total dataset hide important differences across OECD and non-OECD countries: credit scaled by GDP is much higher in OECD than in non-OECD countries, whereas money is broadly the same in both country groups. As a consequence, the ratio of credit to money is higher in OECD countries. Moreover, this ratio has been growing for OECD countries as credit growth has been faster than money growth. Again, we get the opposite picture when looking at non-OECD countries, with money growing faster than credit and, therefore, a falling ratio.

Table 7 displays the same descriptive statistics according to two variables (details provided in the appendix): (i) the FX regime classification, since the management of a fixed regime might lead to a differentiated impact of cross-border capital flows on credit and money compared to floating regimes; and (ii) the share of foreign banks in the domestic banking system as a significant presence of foreign banks is likely associated with higher cross-border financial activity. The statistics show that countries with fixed regimes have, on average, both higher levels and growth rates of credit and money scaled by GDP and of the ratio of both variables. The picture is less clear concerning the share of foreign banks. Countries with high shares have lower levels of credit scaled by both GDP and money. They also have lower credit and money growth rates but a higher average growth of the credit to money ratio.

\footnotetext{
${ }^{7}$ Of course, the problem remains for Greece and Slovenia, that joined the euro area in 2001 and 2007, respectively. All remaining countries that didn't join the euro area at its inception, joined later than 2007: Cyprus and Malta in 2008, Slovakia in 2009 and Estonia in 2011.
} 
As I am chiefly interested in capturing the medium- and long-term relationship between credit and money dynamics and cross-border capital flows, I follow Lane and McQuade (2013) and use multi-year periods. Specifically, I use two four-year periods from 1999 to 2003 and 2003 to 2007. To better assess the interplay of developments in money and credit and cross-border capital flows, I split the countries in the dabatase into terciles according to their credit to money ratios growth in both periods. For each tercile, Table 8 displays the median values of credit, money, the ratio between both variables, the five cross-border flow measures, FX regime classification and the share of foreign banks in the domestic banking sector. In the first tercile, the growth rate of the ratio of credit to money is negative, positive but small in the second and positive and sizeable in the third and last tercile.

These descriptive statistics provide a few interesting insights. First, countries experience higher growth in the ratio of credit to money due to faster credit growth than money. In other words, both variables are growing, one faster than the other. Second, the growth of the credit to money ratio and net debt flows seems to be related: slower ratio growth (or decrease) is associated with negative net flows (i.e., net outflows) or positive and/or smaller net flows (i.e., net inflows) whereas positive and/or faster ratio growth with positive and/or higher net flows. Furthermore, the relationship seems to be more pronounced for the money-issuing than for the money-holding sectors debt flows. At the same time, somewhat of a weaker relation seems to be present for net equity flows of the money-holding sectors in the first and second terciles while there is no apparent relation with money-issuing sectors net equity flows. An inverse relationship between the ratio of credit to money growth and the current account balance also seems to exist: it is positive in the first tercile where the ratio is decreasing and negative in the second and third (higher in the third than in the second) where the ratio is increasing. Finally, faster credit to money ratio growth is associated with a more fixed FX regime and higher share of foreign banks in the domestic banking sector.

To illustrate these patterns, Charts 1 and 2 display quarterly credit and money scaled by GDP and 4-quarter moving sums scaled by GDP of money-issuing and money-holding sectors net debt flows for Estonia and Japan. These two countries provide examples for, respectively, a net importer of capital with a high presence of foreign banks in the domestic banking system and a fixed FX regime and a net exporter of capital with a low presence of foreign banks in the domestic banking system and a 
floating FX regime. Starting with Estonia, credit and money were growing pretty much in line in the beggining of the period: from end-1996 until roughly 1998 there was an initial rise in both variables at the same time that inflows into both the money-issuing and holding sectors were recorded; from 1998 until roughly 2000 both credit and money fell while net outflows were recorded. However, since the early 2000s, credit started to grow faster than money, leading to the decoupling of both variables. This development took place at the same time that consistent and sizeable inflows into the money-issuing sectors were recorded while money-holding sectors flows remained subdued and alternating between inflows and outflows. Turning to Japan, the decline in credit for most of the period goes together with consistent outflows from the money-issuing sectors as well as from the money-holding sectors, albeit smaller. In turn, money barely increases in the period.

In summary, there seems to be a strong comovement between credit and net debt flows, especially in the case of the money-issuing sectors, while broad money seems to move in line with money-holding sectors debt flows. Finally, these relationships are independent of whether the country in question is an overall net exporter or importer of capital, i.e., has a positive or negative current account.

\subsubsection{Euro area}

The euro area aggregate monetary presentation of the balance of payments is published by the ECB but country level data is not available. This paper's database however allows for an in-depth analysis of euro area country level dynamics. One natural and obvious way to organize euro area countries is to split them between core and periphery. In the database there are four core countries - Austria, Finland, France and Germany, - and four periphery countries - Greece, Italy, Portugal and Spain.

The second part of Table 6 displays descriptive statistics for the euro area countries. Importantly, for consistency purposes, the euro area figures presented in this table are the sum of the eight available countries and not aggregate credit or money variables based on euro area residency concepts (see the data appendix for more details).

Developments in credit and money in core and periphery countries are quite disparate. Credit and money scaled by GDP are both higher in periphery countries. The difference is however larger in the case of credit (around ten percentage points) than in the case of money (around five percentage 
points). As a consequence, the ratio of both variables is also higher in periphery countries. Perhaps more striking than the differences in the levels of these variables are the respective growth rates, especially that of credit: whereas credit grew only modestly in core countries, its expansion was much more pronounced in periphery countries. Moreover, credit growth was slower than money growth in core countries, therefore leading to a fall in the credit to money ratio. In contrary, credit grew almost twice as fast as money holdings in periphery countries, thus leading to a widening of the ratio between both variables.

Charts 3 and 4 display credit and money as well as net debt flows of the money-issuing and -holding sectors for Portugal and Germany in the same way as those for Estonia and Japan and illustrate broadly the same ideas. Starting with Portugal, a significant increase in credit took place together with a spike in inflows into the money-issuing sectors from 1999 to 2003. A period of subdued inflows and credit growth then took place. Strong credit growth resumed from roughly 2005, coupled with a new wave of sizeable money-issuing sectors inflows. Money decreased slightly from 1999 to 2004, at the same time that outflows were recorded for the money-holding sectors. From then on, money increased alongside inflows into the money-holding sectors. Turning to Germany, after an initial period up until roughly 2000 of credit growth and inflows into the money-issuing sectors, credit was constantly decreasing at the same time that outflows were recorded for the money-issuing sectors. In turn, money was almost always increasing.

\section{Econometrics}

\subsection{Empirical approach}

The cross-sectional empirical specification closely follows Lane and McQuade (2013) and is given by

$$
\begin{aligned}
\left(X_{i t}-X_{i t-s}\right) & =\beta_{p}^{1}+\beta_{p}^{2} X_{i t-s}+\beta_{p}^{3} \log \left(G D P_{i t-s}^{p c}\right)+\beta_{p}^{4} F X_{i t-s}+\beta_{p}^{5} S F O R E I G N_{i t-s} \beta_{p}^{6} \text { NOECD }+ \\
& +\beta_{p}^{7} \sum_{k=t-(s+1)}^{t} F L+\varepsilon_{i p}
\end{aligned}
$$


The left hand side variables $X$ are either credit or money - both scaled by GDP - or the ratio of credit to money. Moving on to the right hand side variables, $X$ is the initial level of the three variables and $G D P^{p c}$ is the initial level of GDP per capita. Both co-variates are intended to capture potential convergence effects, whereby countries with smaller initial levels of credit/money and output per capita might be undergoing a catch up effect and, for this reason, experiencing faster growth. Turning to $F X$, this is a dummy variable for the FX regime classification, assuming value 1 in the case of fixed regimes and 0 otherwise. SFOREIGN is the share of foreign banks in total bank assets proxied by the local claims of foreign affiliates in a given country, taken from the BIS banking statistics, and scaled by private credit. In turn, NOECD is a dummy variable taking value 1 for countries that do not belong to the OECD and 0 otherwise. Finally, FL are the cross-border capital flow measures. I use net equity and debt flows of the money-issuing and -holding sectors as well as the current account balance (4-year averages, scaled by GDP). The index $p$ in the regression coefficients stands for the two time periods considered.

\subsection{Results}

Tables 9,10 and 11 display, respectively, results for credit, money and the ratio between both variables. The first can be thought of as an asset side regression, the second as a liability side regression and the third combines both the asset and liability sides.

Starting with the credit regressions in Table 9, credit growth displays overall a statistically significant comovement with net debt flows, especially in the 2003-2007 period and in the pooled regression. Moreover, the signs are those expected: a positive coefficient means that net inflows are associated with credit growth. The only exception is in the 1999-2003, where the coefficient on net equity flows of the money-holding sectors is significant. However, in this instance, net flows are associated to a lower credit, as the coefficient is negative. These results are therefore consistent with the findings in Lane and McQuade (2013) in the sense that debt is the significant component in explaining credit growth. Furthermore, within net debt flows, those of the money-issuing sectors seem to have a stronger comovement with credit than those of the money-holding sectors, which are mostly relevant in the pooled regression only. 
The picture is completely different in the money regressions in Table 10 . First of all, only moneyholding sectors flows are relevant in explaining money dynamics; in no instance are money-issuing sectors flows significant. Again, net debt flows seem to be more powerful than net equity flows as the latter are only barely significant in the pooled regression. Moreover, in that particular case, the coefficient is negative, indicating that equity flows are associated with negative money growth.

Finally, turning to the credit to money ratio in Table 11, there is an evident and strong relation between money-issuing sectors debt flows in both periods and in the pooled regression. At the same time, interestingly, money-holding sectors debt flows are not statistically significant. Finally, moneyholding sectors equity flows are only tenuously significant in the 2003-2007 period and with a positive coefficient: putting this result together with those of both previous sets of regressions, while moneyissuing debt flows are likely associated with a higher credit to money ratio via a numerator effect, money-holding sectors equity flows have the same effect working via a denominator effect, i.e., by reducing money holdings.

Throughout the whole analysis, the current account exhibits a statistically significant comovement with the three variables and the periods under consideration, with only few exceptions. This clearly shows that focusing on broad measures such as the current account might be seriously misleading given the differentiated roles of the instrument and sectoral composition play.

In some countries, intra-company loans may represent a significant cross-border source of funding to non-financial corporations. Although they are formally recorded within FDI, and therefore considered equity, they are in essence loans like others recorded elsewhere in the financial account - in other investment or in portfolio investment, since they can also take the form of debt securities - whereby companies in the same group provide funds to one another. Furthermore, these loans might also represents a source of inconsistencies, since as explained in detail in the appendix, intra-company loans in the case of financial corporations are recorded under other investment. For this reason, and to assess whether taking these loans as equity could be biasing the results, I reran the regressions considering the debt component of FDI within debt and only the remaining components of capital and reinvested earnings as equity (again more details on this alternative specification are provided in the data appendix). Results are displayed in Table 12 and they are qualitatively the same (I report 
only the results for the credit to money ratio). Net equity flows of the money-holding sectors are now more robust, especially in the 2003-2007 period but still positive and fully consistent with the picture provided by the previous regressions.

\section{Concluding remarks}

This paper has looked at the relationship between credit, money and international capital flows. It has showed that, in addition to the debt/equity breakdown, the sectoral composition of flows is an important component with different implications for domestic credit and money holdings. In particular, while net debt flows of non-banks display comovement with broad money, net debt flows of banks seem to be more relevant in explaining credit dynamics and are conducive to the decoupling between both variables.

The reason for this differentiated impact of flows seems to be the non-monetary nature of the crossborder banking activity: it provides domestic banks with funds to further lend domestically to the non-bank private sectors without expanding money holdings. In other words, more than contributing to credit growth and the expansion of the asset side of domestic banks balance sheets, the crossborder banking activity and wholesale funding have contributed to alter the mix between monetary and non-monetary liabilities of banks.

These results have important implications and lessons for financial stability and macroprundential policy and point to the need of carefully monitoring the cross-border element when assessing developments in credit and money. Shin (2013) argues that the non-core liabilities of banks - and therein especially external ones - are strongly associated with the vulnerability to a crisis. Hoggarth et al. (2010) discuss how foreign sources of funding are typically more volatile and procyclical than domestic sources and Hoggarth et al. (2013) discuss how foreign affiliates in the UK, which operate mostly using non-resident funding, were more volatile than UK-owned banks once the crisis erupted. Finally, one key element stressed by these results is the need to better understand the role of global banks, how they operate and provide liquidity worlwide - examples of work in that area are Cetorelli and Goldberg (2011, 2012), Bruno and Shin (2013), McCauley (2012) and Niepmann (2013). 


\section{A Data Appendix}

The starting point for the country coverage was the OECD countries. To these I also added a significant number of other countries, mostly Asian and Latin American. Unfortunatelly, for data availibility reasons, the country coverage is smaller than that. The complete list of countries and with the time period for which data is available is in Table 3. This list is the intersection of the data availability across the three variables: credit, money and capital flows. More details for the different variables are provided in the next subsections.

\section{A.1 Credit and money aggregates}

The data for credit and money aggregates from the IFS CR-ROM version of August 2012.

Starting with credit, I follow Lane and McQuade (2013) and use the claims of depositary corporations on other private sectors available at the IMF IFS dataset (line 22d). For some countries there are breaks in these series, mostly from 2000 to 2001. In these cases, I remove the initial data points and start in 2001 only.

Regarding money aggregates, there are two types in IFS: the standardized report forms (SRFs) and the national definitions of money (NDMs). For consistency sake, I use the SRFs to the extent possible. I focus on a broad monetary aggregate and choose M3 as default. Whenever it's not available, I use M2. If neither is available in the SRFs, I resort to the NDMs or to other broad money definitions.

Finally, both credit and money series are provided in national currency. I convert them to US dollars using end-period exchange rates, also taken from the IFS dataset.

\section{A.1.1 Euro area countries money aggregates}

The ECB compiles and publishes euro area money aggregates which are built using country level data of the individual member states' contributions to both the aggregate and consolidated euro area MFI balance sheet. The contributions are compiled using the euro area wide residency concept, i.e., excluding intra-euro area positions. Therefore, these data are not suited to build individual countries' money aggregates and the ECB doesn't publish alternative public data. However, the IMF publishes 
depository corporations balance sheet data of euro area member states according to a national residency concept - the same as balance of payments statistics - in the IFS statistics database.

The breakdowns are not exactly the same as the ones the ECB uses to build the euro area aggregates. Specifically, the split between different types of deposits - overnight deposits, deposits with an agreed maturity up to 2 years, deposits redeemable at a period of notice up to 3 months - as well as repurchase agreements is not available. One can nevertheless construct broad money aggregates similar to the ECB's definition for the euro area. In order to get concepts as close as possible to the ECB, I define M2 as the sum of currency in circulation, transferable and other deposits and M3 as M2 plus securities other than shares with a maturity up to two years and money market fund shares. Given the lack of detail within deposits, I ignore M1 (see Figure 2).

\section{A.2 Capital flows}

I construct the monetary presentation of the balance of payments along the lines of Bê Duc et al. $(2008)_{8}^{8}$ which boils down (almost exclusively) to applying a sectoral breakdown and distinguishing external transactions of the money-holding sector from those of the money-issuing. Starting with the basic identity of the balance of payments

$$
C A+K A+F A+E O=0
$$

where $C A$ is the current account, $K A$ the capital account, $F A$ the financial account and $E O$ the residual errors and omissions. Breaking the financial account into transactions of the money holding (FAMH) and the issuing sectors (FAMI), we can rewrite the expression as

$$
C A+K A+F A M I+F A M H+E O=0
$$

There are, however, some limitations concerning items for which this breakdown is not available. This is the case of the current and capital accounts, as well as the item errors and omissions, the statistical discrepancy. For these items, and again following Bê Duc et al. (2008), I assume that they

\footnotetext{
${ }^{8}$ see also Bank of England (2005)
} 
reflect money-holding sectors' transactions. Thus, we can write $N E T M I=F A M I$ and NETMH = $F A M H+C A+K A+E O$. Finally, recalling that $N E T M I+N E T M H=0$

$$
N E T M I=\triangle N E A=-C A-K A-F A M H-E O
$$

Specifically, I construct total net financial flows for the four sectors available - monetary authority, MFIs, general government and other sectors - the outcome could be thought of a financial account for each of them. Net financial flows for the money issuing and money holding sectors are computed as the result of adding, respectively, on the one hand, net flows for the monetary authority and MFIs and, on the other hand, net flows of the general government and other sectors. Further breakdowns are available for equity and debt. Finally, total money-holding sector flows are obtained by adding the current and capital accounts as well as errors and omissions to the financial flows of those sectors. However, my focus is on financial account flows and their split into equity and debt.

The data are taken from the IMF balance of payments dataset, from the January 2012 CD ROM version. There is one limitation concerning FDI as the split between other sectors and banks is not available. However, this shouldn't be a significant caveat since, to a large extent, FDI should be associated to other sectors and not banks. Moreover, by definition, only equity positions of banks should be recorded in FDI, all other types of transactions (mainly loans between affiliates) should be recorded under other investment, which minimizes the impact of the lack of sectoral breakdown in this particular item (see $\S 6.28$ of IMF, 2009). To assess whether intra-company loans of other sectors might be influecing results across the equity/debt split, I also constructed an alternative version of the monetary presentation, assuming that these loans are debt and not equity.

\section{A.3 Other variables}

- Starting with GDP per capita, GDP data is from the IMF World Economic Outlook and population data from the World Bank.

- On the FX regime, this is a dummy variable constructed using Reinhart and Rogoff's (2009) FX regime classification. Specifically, this classification assigns values from 1 to 4 , where 1 
corresponds to fully fixed regimes and 4 to floating regimes. I take classifications 1 and 2 as fixed regimes and 3 and 4 as floating. The data are taken from the book's website.

- Data for the local claims used for the proxy on the share of foreign banks in the domestic banking sector are from the BIS consolidated banking statistics, taken from the BIS website. Specifically, these correspond to the local currency claims on local residents by all reporting banks and countries on an immediate borrower basis. The share of foreign banks in the domestic banking sector is obtained by scaling the claims by credit. For the purpose of Table 7 , countries with low presence of foreign banks are defined as being below the median value in the 1999-2007 period and high presence of foreign banks are defined as being above. Claessens and van Horen (2013) create a database with the nationality of banks in the banking systems of a large sample of countries. With these data, they compute the percentage of foreign banks among total banks. They also develop an indicator of the percentage of foreign bank assets among total bank assets which would be ideal for the purposes of this analysis. However, their indicator only starts in 2004 due to Bankscope data availability. For this reason, I use instead a proxy for foreign banking activity with BIS data.

- Data for the change in net external claims used for the flow measures correlations are from the BIS locational banking statistics, taken from the BIS website. These are claims of domestic residents on foreign residents net of responsibilities of domestic residents to foreign residents by all reporting banks and countries. 


\section{References}

[1] Baeriswyl, R. and M. Ganarin (2011), "The non-inflationary Great Leverage", mimeo, Swiss National Bank.

[2] Bank of England (2006), "Monetary and financial statistics", Centre for Central Banking Studies, Bank of England Handbooks in Central Banking No. 25.

[3] Bê Duc, L., F. Mayerlen and P. Sola (2008), "The monetary presentation of the euro area balance of payments", European Central Bank Occasional Paper No. 96.

[4] Bordo, M., B. Eichengreen, D. Klingebiel and M. S. Martinez-Peria (2001), "Is the Crisis Problem Growing More Severe?", Economic Policy: A European Forum 32: pp.5175.

[5] Bruno, V. and H. S. Shin (2013), "Capital flows, cross-border banking and global liquidity", NBER Working Paper No. 18942.

[6] Cetorelli, N. and L. S. Goldberg (2011), "Global banks and international shock transmission: evidence from the crisis ", International Monetary Fund Economic Review 59(1), pp. 41-76.

[7] Cetorelli, N. and L. S. Goldberg (2012), "Banking globalization and monetary transmission ", Journal of Finance 67(5), pp. 1811-1843.

[8] Claessens, S. and N. van Horen (2012), "Foreign banks: trends, impact and financial stability", International Monetary Fund Working Paper No. 12/10.

[9] Dembiermont, C., M. Drehmann and S. Muksakunratana (2013), "How much does the private sector really borrow? A new database for total credit to the private non-financial sector ", Bank for International International Quarterly Review March 2013, pp.65-81.

[10] ECB (2008), "The external dimension of monetary analysis ", European Central Bank Monthly Bulletin August 2008, pp. 71-84.

[11] Friedman, M. (1970), "The Counter-Revolution in Monetary Theory", Institute of Economic Affairs Occasional Paper No. 33. 
[12] Forbes, K. and F. Warnock (2012), "Capital flow waves: Surges, stops, flight, and retrenchment", Journal of International Economics 88(2), pp. 235-251.

[13] Hahm, J.-H., H.S. Shin and K. Shin (2011), "Non core bank liabilities and financial vulnerability", NBER Working Paper No. 18428.

[14] Hoggarth, G., L. Mahadeva and J. Martin (2010), "Understanding international bank capital flows during the recent financial crisis", Financial Stability Paper No. 8, Bank of England.

[15] Hoggarth, G., J. Hooley and Y. Korniyenko (2013), "Which way do foreign branches sway? Evidence from the recent UK domestic credit cycle", Financial Stability Paper No. 22, Bank of England.

[16] International Monetary Fund (2009), "Balance of payments and international investiment position manual 6th edition", International Monetary Fund.

[17] Jordà, O., M. Schularick and A. P. Taylor (2012), "When credit bites back leverage business cycles and crises", Economic Policy: A European Forum 32: pp.5175.

[18] Jordà, O., M. Schularick and A. P. Taylor (2013), "Sovereigns versus banks: crises, causes and consequences", CEPR Discussion Paper No. 9678.

[19] Johnson, H. (1972), "The monetary approach to balance of payments theory", The Journal of Financial and Quantitative Analysis, Vol. 7, No. 2, Supplement: Outlook for the Securities Industry (Mar., 1972), pp. 1555-1572.

[20] Kemp, D. S. (1975), "A monetary view of the balance of payments", Federal Reserve Bank of St. Louis, pp. 14-22.

[21] Lane, P. and G. M. Milesi-Ferretti (2012), "External adjustment and the global crisis", Journal of International Economics 88(2), pp. 252-265.

[22] Lane, P. and P. McQuade (2013), "Domestic credit growth and international capital flows", European Central Bank Working Paper No. 1566. 
[23] McCauley, R. N. (2012), "Risk-on/risk-off, capital flows, leverage and safe assets", Bank for International Settlements Working Paper No. 382.

[24] Niepmann, F. (2013), "Banking across borders", mimeo, Federal Reserve Bank of New York.

[25] Polak, J.J. (2001), "The Two Monetary Approaches to the Balance of Payments: Keynesian and Johnsonian", International Monetary Fund Working Paper 01/100

[26] Reinhart, C. and V. Reinhart (2008), "Capital flow bonanzas an encompassing view of the past and present", National Bureau of Economic Research, Working paper No. 14321.

[27] Reinhart, C. and K. Rogoff (2009), "This time is different - Eight centuries of financial folly ", Princeton University Press.

[28] Schularik, M. and A. M. Taylor (2012), "Credit booms gone bust: monetary policy, leverage cycles, and financial crises, 1870-2008", American Economic Review 102(2), pp. 1029-1061.

[29] Spiegel, M. M. (2009a), "Monetary and Financial Integration in the EMU: Push or Pull?", Review of International Economics 17(4), pp. 751776.

[30] Spiegel, M. M. (2009b), "Monetary and financial integration: Evidence from the EMU", Journal of The Japanese and International Economies 23, pp. 114130.

[31] Taylor, A. M. (2012), "The Great Leveraging ", Centre for Economic Policy Research, Discussion Paper 9082. 
Table 1: Consolidated aggregate MFI balance sheet

\begin{tabular}{l|l}
\multicolumn{1}{c}{ Assets } & \multicolumn{1}{c}{ Liabilities } \\
\hline \multirow{2}{*}{ Loans to domestic non-banks } & \multicolumn{1}{c}{ Broad money } \\
& Currency in circulation \\
& Deposits (liquid) \\
Money market fund shares & Repurchase agreements \\
& Debt securities (with limited maturity) \\
Claims on non-residents (external assets) & Financial liabilities to non-residents (external liabilities) \\
& Deposits and loans received from non-residents \\
& \multicolumn{1}{c}{ Non-monetary liabilities } \\
& Longer-term financial liabilities \\
& Deposits and loans with agreed maturity \\
& Deposits redeemable at a period of notice of over 3 months \\
Other domestic assets & Capital, reserves and provisions \\
including fixed assets & Other liabilities \\
& including deposits by central government
\end{tabular}

Table 2: Definition of euro area money aggregates

\begin{tabular}{|c|c|c|c|}
\hline \multicolumn{4}{|l|}{ ECB's definition of euro area money aggregates } \\
\hline & M1 & M2 & M3 \\
\hline Currency in circulation & $\mathrm{X}$ & $\mathrm{X}$ & $\mathrm{X}$ \\
\hline Overnight deposits & $\mathrm{X}$ & $\mathrm{X}$ & $\mathrm{X}$ \\
\hline Deposits with an agreed maturity up to 2 years & & $\mathrm{X}$ & $\mathrm{X}$ \\
\hline Deposits redeemable at a period of notice up to 3 months & & $\mathrm{X}$ & $\mathrm{X}$ \\
\hline Repurchase agreements & & & $\mathrm{X}$ \\
\hline Money market fund shares/units & & & $\mathrm{X}$ \\
\hline Debt securities up to 2 years & & & $\mathrm{X}$ \\
\hline \multicolumn{4}{|l|}{ EA countries' monetary aggregates using IFS data } \\
\hline & & M2 & M3 \\
\hline Currency in circulation & & $\mathrm{X}$ & $\mathrm{X}$ \\
\hline Transferable deposits & & $\mathrm{X}$ & $\mathrm{X}$ \\
\hline Other deposits & & $\mathrm{X}$ & $\mathrm{X}$ \\
\hline Money market fund shares/units & & & $\mathrm{X}$ \\
\hline Debt securities up to 2 years & & & $\mathrm{X}$ \\
\hline
\end{tabular}


Figure 1: Credit, money and cross-border debt flows - Estonia

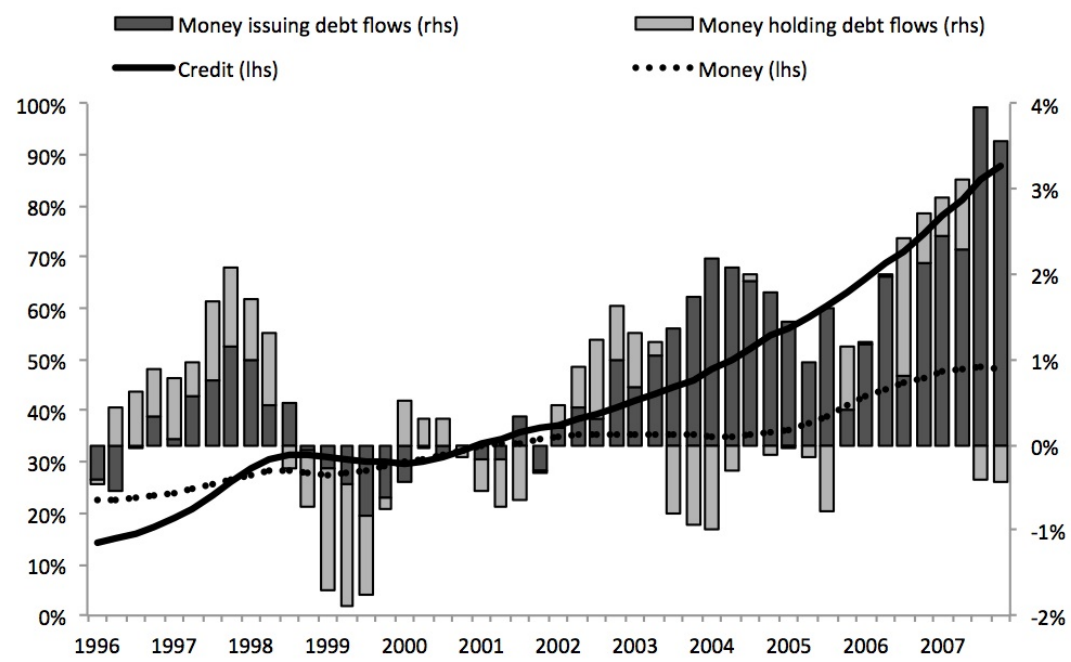

Figure 2: Credit, money and cross-border debt flows - Japan

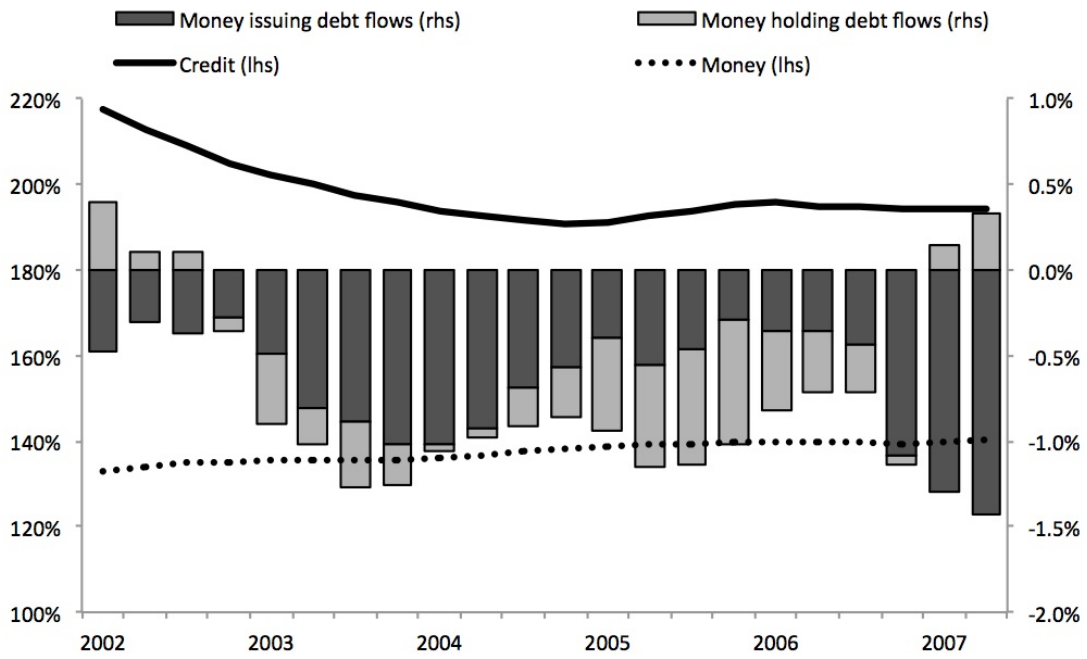


Figure 3: Credit, money and cross-border debt flows - Portugal

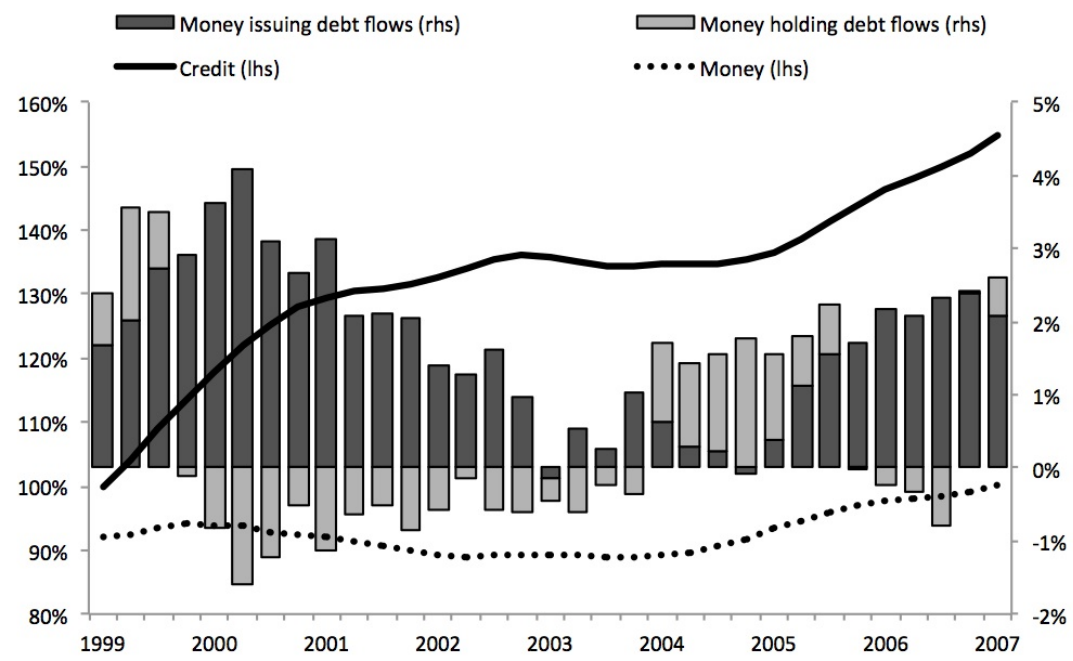

Figure 4: Credit, money and cross-border debt flows - Germany

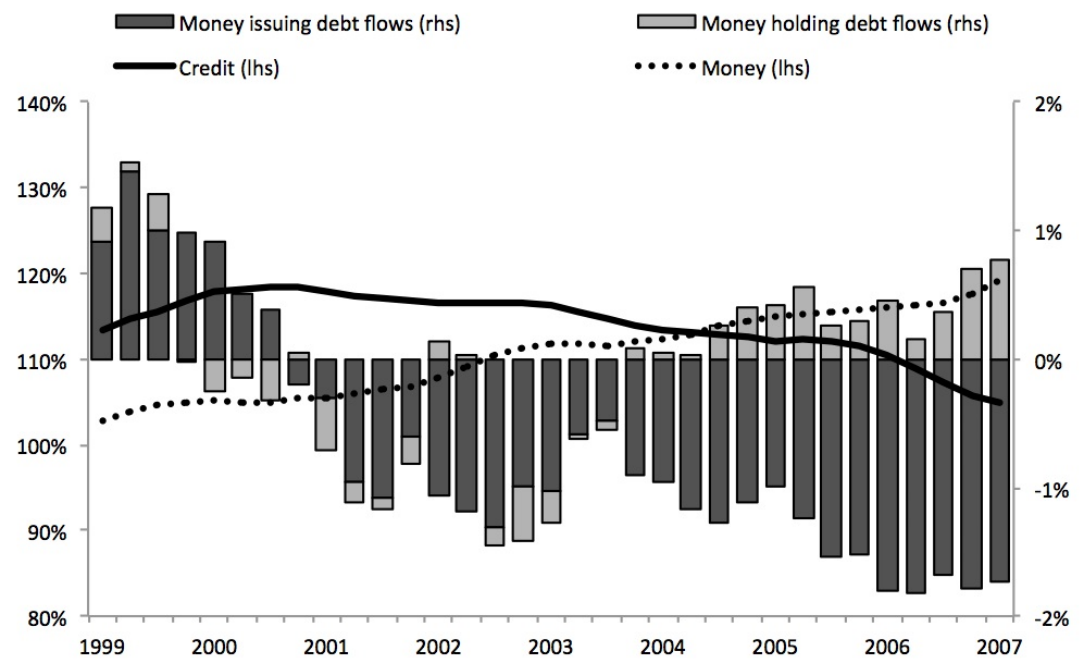


Figure 5: Credit growth and net debt of the money-issuing sectors

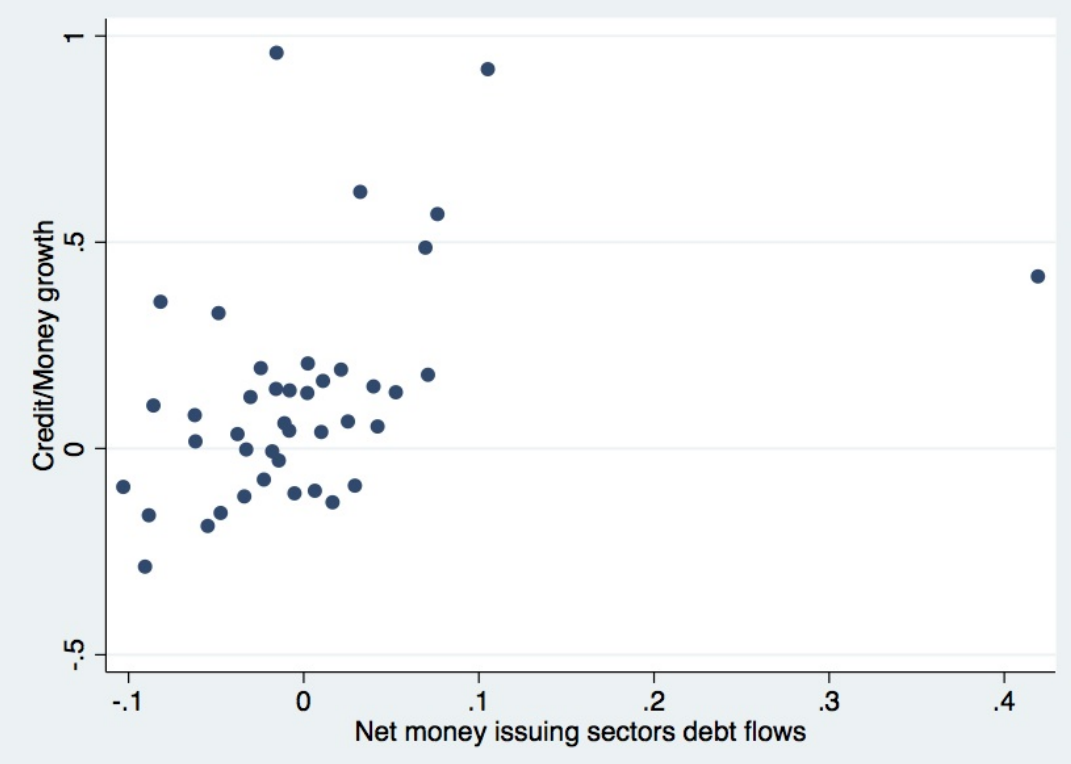


Table 3: Data availability

\begin{tabular}{lcc|lcc}
\hline \hline Country & Initial & Final & Country & Initial & Final \\
\hline Argentina & 1998 & 2010 & Latvia & 2003 & 2008 \\
Australia & 1990 & 2003 & Lithuania & 1996 & 2008 \\
Austria & 1999 & 2005 & Luxembourg & 2003 & 2010 \\
Bolivia & 1997 & 2010 & Malaysia & 2002 & 2009 \\
Brazil & 1995 & 2010 & Malta & 1995 & 2007 \\
Bulgaria & 1995 & 2008 & Mexico & 1996 & 2010 \\
Canada & 2001 & 2008 & Morocco & 2003 & 2009 \\
Chile & 1996 & 2010 & Norway & 1994 & 2006 \\
Colombia & 1996 & 2010 & Peru & 1992 & 2010 \\
Cyprus & 2001 & 2007 & Philippines & 1996 & 2007 \\
Czech Republic & 2002 & 2008 & Poland & 2000 & 2008 \\
Denmark & 2000 & 2008 & Portugal & 1999 & 2010 \\
El Salvador & 2001 & 2010 & Romania & 2001 & 2010 \\
Estonia & 1993 & 2010 & Russia & 2000 & 2010 \\
Finland & 1999 & 2006 & Slovakia & 2000 & 2008 \\
France & 1999 & 2010 & Slovenia & 1994 & 2006 \\
Germany & 1999 & 2010 & South Africa & 1992 & 2010 \\
Greece & 2001 & 2010 & Spain & 1999 & 2010 \\
Guatemala & 1997 & 2010 & Sweden & 2001 & 2008 \\
Hong Kong & 2001 & 2010 & Thailand & 1997 & 2010 \\
Hungary & 1995 & 2008 & Turkey & 1990 & 2010 \\
Iceland & 2000 & 2007 & United Kingdom & 1990 & 2010 \\
Israel & 1990 & 2010 & Uruguay & 2001 & 2010 \\
Italy & 1999 & 2010 & Vietnam & 1996 & 2010 \\
Japan & 2001 & 2010 & & & \\
\hline \hline Note: No money aggregates for Israel and Vietnam & &
\end{tabular}


Table 4: Broad money aggregates

\begin{tabular}{lcc|lcc}
\hline \hline Country & Source & Series & Country & Source & Series \\
\hline Argentina & SRF & M3 & Latvia & SRF & M3 \\
Australia & SRF & M3 & Lithuania & SRF & M2 \\
Austria & Est & M3 & Luxembourg & Est & M3 \\
Bolivia & NDM & M'4 & Malaysia & SRF & M3 \\
Brazil & SRF & M3 & Malta & SRF & M3 \\
Bulgaria & SRF & M3 & Mexico & SRF & M3 \\
Canada & NDM & M3 GROSS & Morocco & SRF & M3 \\
Chile & SRF & M3 & Norway & SRF & BROAD MONEY(M2) \\
Colombia & SRF & M3 & Peru & SRF & LIQUIDITY \\
Cyprus & SRF & M2 & Philippines & SRF & M3 \\
Czech Republic & SRF & M3 & Poland & SRF & M3 \\
Denmark & SRF & M3 & Portugal & Est & M3 \\
El Salvador & SRF & M3 & Romania & SRF & BROAD MONEY \\
Estonia & SRF & M2 & Russia & SRF & BROAD MONEY \\
Finland & Est & M3 & Slovakia & SRF & M2 \\
France & Est & M3 & Slovenia & SRF & M3 \\
Germany & Est & M3 & South Africa & SRF & M3 \\
Greece & Est & M3 & Spain & Est & M3 \\
Guatemala & SRF & M2 & Sweden & SRF & M3 \\
Hong Kong & SRF & M3 & Thailand & NDM & BROAD MONEY \\
Hungary & SRF & M3 & Turkey & SRF & M3 \\
Iceland & SRF & M3 & United Kingdom & NDM & M4 \\
Israel & - & - & Uruguay & SRF & BROAD MONEY \\
Italy & Est & M3 & Vietnam & - & - \\
Japan & SRF & M3 & & & \\
\hline \hline Note: "Est" are author own estimations. No money aggregates for Israel and Vietnam
\end{tabular}

Table 5: Correlations of capital flow measures - 1999-2007 period

\begin{tabular}{lc}
\hline \hline & BIS derived flows \\
MISSUINGD & 0.869 \\
MHOLDINGD & -0.414 \\
MISSUINGE & -0.421 \\
MHOLDINGE & -0.639 \\
CAB & -0.148 \\
\hline \hline MISSUINGD is net debt flows of the money-issuing sectors, MHOLDINGD is \\
net debt flows of the money-holding sectors, MISSUINGE is net equity flows of \\
the money-issuing sectors, MHOLDINGE is net equity flows of the money-holding \\
sectors, CAB is the current account balance.
\end{tabular}


Table 6: Summary statistics by country group, 1999-2007 period

\begin{tabular}{|c|c|c|c|c|c|c|}
\hline & $\overline{\mathrm{C} / \mathrm{GDP}}$ & $\overline{\mathrm{M} / \mathrm{GDP}}$ & $\mathrm{C} / \mathrm{M}$ & $\Delta \mathrm{C} / \mathrm{GDP}$ & $\Delta \mathrm{M} / \mathrm{GDP}$ & $\Delta \mathrm{C} / \mathrm{M}$ \\
\hline \multicolumn{7}{|c|}{$O E C D$} \\
\hline $\mathrm{N}$ & 280 & 266 & 258 & 248 & 235 & 227 \\
\hline Mean & 0.838 & 0.746 & 1.194 & 0.058 & 0.029 & 0.035 \\
\hline $\mathrm{SD}$ & 0.515 & 0.396 & 0.660 & 0.109 & 0.086 & 0.186 \\
\hline \multicolumn{7}{|c|}{ Non OECD } \\
\hline $\mathrm{N}$ & 144 & 126 & 126 & 128 & 111 & 111 \\
\hline Mean & 0.554 & 0.719 & 0.856 & 0.006 & 0.019 & -0.014 \\
\hline $\mathrm{SD}$ & 0.375 & 0.693 & 0.287 & 0.068 & 0.081 & 0.108 \\
\hline \multicolumn{7}{|c|}{ Euro area } \\
\hline $\mathrm{N}$ & 72 & 70 & 70 & 64 & 62 & 62 \\
\hline Mean & 1.025 & 0.857 & 1.224 & 0.063 & 0.035 & 0.025 \\
\hline $\mathrm{SD}$ & 0.316 & 0.216 & 0.212 & 0.096 & 0.073 & 0.053 \\
\hline \multicolumn{7}{|c|}{ Euro area core } \\
\hline $\mathrm{N}$ & 36 & 36 & 36 & 32 & 32 & 32 \\
\hline Mean & 0.978 & 0.831 & 1.189 & 0.034 & 0.026 & 0.011 \\
\hline $\mathrm{SD}$ & 0.222 & 0.217 & 0.104 & 0.076 & 0.064 & 0.051 \\
\hline \multicolumn{7}{|c|}{ Euro area periphery } \\
\hline $\mathrm{N}$ & 36 & 34 & 34 & 32 & 30 & 30 \\
\hline Mean & 1.071 & 0.885 & 1.261 & 0.092 & 0.044 & 0.041 \\
\hline SD & 0.386 & 0.214 & 0.283 & 0.106 & 0.081 & 0.051 \\
\hline
\end{tabular}

$C / G D P$ is credit scaled by $G D P, M / G D P$ is money scaled by $G D P, C / M$ is the credit to money ratio. 
Table 7: Summary statistics by FX regime and foreign bank presence - 1999-2007 period

\begin{tabular}{|c|c|c|c|c|c|c|}
\hline & $\bar{c} \mathrm{C} / \mathrm{GDP}$ & "M/GDP & $\overline{\mathrm{C} / \mathrm{M}}$ & 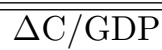 & 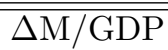 & $\overline{\overline{\Delta \mathrm{C} / \mathrm{M}}}$ \\
\hline \multicolumn{7}{|c|}{ Total } \\
\hline $\mathrm{N}$ & 424 & 392 & 384 & 376 & 346 & 338 \\
\hline Mean & 0.742 & 0.737 & 1.083 & 0.040 & 0.026 & 0.019 \\
\hline SD & 0.490 & 0.510 & 0.587 & 0.100 & 0.084 & 0.166 \\
\hline \multicolumn{7}{|c|}{ Fixed FX } \\
\hline $\mathrm{N}$ & 195 & 181 & 180 & 176 & 162 & 161 \\
\hline Mean & 0.866 & 0.855 & 1.135 & 0.051 & 0.035 & 0.034 \\
\hline $\mathrm{SD}$ & 0.473 & 0.592 & 0.579 & 0.097 & 0.092 & 0.087 \\
\hline \multicolumn{7}{|c|}{ Floating FX } \\
\hline $\mathrm{N}$ & 226 & 211 & 204 & 198 & 184 & 177 \\
\hline Mean & 0.639 & 0.636 & 1.036 & 0.031 & 0.018 & 0.005 \\
\hline $\mathrm{SD}$ & 0.482 & 0.401 & 0.591 & 0.103 & 0.076 & 0.213 \\
\hline \multicolumn{7}{|c|}{ High share foreign banks } \\
\hline $\mathrm{N}$ & 213 & 208 & 200 & 198 & 189 & 185 \\
\hline Mean & 0.639 & 0.749 & 0.906 & 0.027 & 0.021 & 0.021 \\
\hline SD & 0.445 & 0.581 & 0.448 & 0.078 & 0.083 & 0.095 \\
\hline \multicolumn{7}{|c|}{ Low share foreign banks } \\
\hline $\mathrm{N}$ & 211 & 184 & 184 & 178 & 157 & 153 \\
\hline Mean & 0.846 & 0.724 & 1.275 & 0.056 & 0.031 & 0.016 \\
\hline SD & 0.513 & 0.416 & 0.656 & 0.119 & 0.086 & 0.224 \\
\hline
\end{tabular}


Table 8: Credit to money growth - Terciles

\begin{tabular}{l|ccc|ccc}
\hline \hline & \multicolumn{3}{|c|}{$1999-2003$} & \multicolumn{3}{c}{ 2003-2007 } \\
& Tercile 1 & Tercile 2 & Tercile 3 & Tercile 1 & Tercile 2 & Tercile 3 \\
\hline C/GDP & -0.051 & 0.151 & 0.270 & 0.018 & 0.135 & 0.385 \\
M/GDP & -0.023 & 0.164 & 0.131 & 0.063 & 0.060 & 0.102 \\
C/M & -0.129 & 0.035 & 0.223 & -0.103 & 0.065 & 0.328 \\
MISSUINGD & -0.120 & -0.002 & 0.011 & -0.028 & -0.010 & 0.027 \\
MHOLDINGD & 0.004 & 0.015 & 0.005 & -0.004 & 0.005 & 0.017 \\
MISSUINGE & 0.000 & -0.000 & 0.000 & 0.000 & 0.000 & -0.001 \\
MHOLDINGE & 0.017 & 0.010 & 0.004 & 0.007 & 0.022 & 0.021 \\
CAB & -0.010 & -0.011 & -0.041 & 0.016 & -0.026 & -0.077 \\
FX & 3 & 1.5 & 1 & 3 & 3 & 1 \\
SFOREIGN & 0.229 & 0.218 & 0.122 & 0.214 & 0.234 & 0.327 \\
\hline \hline
\end{tabular}

Note: countries divided into terciles according to the ratio of credit to money in the 19992003 and 2003-2007 period. Countries in the first tercile have the slowest growth whereas those in the third tercile have the fastest growth. Figures presented are the median values within each of the three terciles for both periods. C/GDP is credit scaled by GDP, M/GDP is money scaled by GDP, $\mathrm{C} / \mathrm{M}$ is the credit to money ratio, MISSUINGD is net debt flows of the money-issuing sectors, MHOLDINGD is net debt flows of the money-holding sectors, MISSUINGE is net equity flows of the money-issuing sectors, MHOLDINGE is net equity flows of the money-holding sectors, $\mathrm{CAB}$ is the current account balance, FX is a dummy for the FX regime, SFOREIGN is the share of foreign banks in total bank assets. 
Table 9: Credit regressions

\begin{tabular}{|c|c|c|c|c|c|c|}
\hline & 99-03 & 99-03 & 203-07 & 03-07 & Pooled & Pooled \\
\hline$C R E D I T_{0}$ & $\begin{array}{l}-0.07 \\
(0.10)\end{array}$ & $\begin{array}{c}0.04 \\
(0.10)\end{array}$ & $\begin{array}{c}0.03 \\
(0.09)\end{array}$ & $\begin{array}{c}0.06 \\
(0.08)\end{array}$ & $\begin{array}{l}-0.05 \\
(0.06)\end{array}$ & $\begin{array}{l}-0.02 \\
(0.05)\end{array}$ \\
\hline $\log (\mathrm{GDPpc})$ & $\begin{array}{l}0.07^{*} \\
(0.04)\end{array}$ & $\begin{array}{l}-0.04 \\
(0.04)\end{array}$ & $\begin{array}{c}0.03 \\
(0.06)\end{array}$ & $\begin{array}{l}-0.08 \\
(0.05)\end{array}$ & $\begin{array}{l}0.06^{*} \\
(0.03)\end{array}$ & $\begin{array}{l}-0.01 \\
(0.03)\end{array}$ \\
\hline SFOREIGN & $\begin{array}{c}-0.42^{* *} \\
(0.16)\end{array}$ & $\begin{array}{l}-0.14 \\
(0.11)\end{array}$ & $\begin{array}{c}-0.16^{* *} \\
(0.07)\end{array}$ & $\begin{array}{l}-0.07 \\
(0.06)\end{array}$ & $\begin{array}{c}-0.23^{* * *} \\
(0.07)\end{array}$ & $\begin{array}{c}-0.11^{* *} \\
(0.05)\end{array}$ \\
\hline FX & $\begin{array}{l}-0.00 \\
(0.07)\end{array}$ & $\begin{array}{c}0.04 \\
(0.05)\end{array}$ & $\begin{array}{l}-0.08 \\
(0.09)\end{array}$ & $\begin{array}{l}-0.01 \\
(0.04)\end{array}$ & $\begin{array}{l}-0.04 \\
(0.06)\end{array}$ & $\begin{array}{c}0.02 \\
(0.04)\end{array}$ \\
\hline NOECD & $\begin{array}{l}-0.09 \\
(0.08)\end{array}$ & $\begin{array}{c}-0.15^{* *} \\
(0.06)\end{array}$ & $\begin{array}{l}-0.05 \\
(0.11)\end{array}$ & $\begin{array}{l}-0.12 \\
(0.09)\end{array}$ & $\begin{array}{l}-0.07 \\
(0.06)\end{array}$ & $\begin{array}{c}-0.10^{* * *} \\
(0.05)\end{array}$ \\
\hline $\mathrm{CAB}$ & $\begin{array}{l}-1.12 \\
(0.87)\end{array}$ & & $\begin{array}{c}-2.40^{* *} \\
(0.94)\end{array}$ & & $\begin{array}{c}-1.86^{* * *} \\
(0.68)\end{array}$ & \\
\hline MISSUINGD & & $\begin{array}{l}2.21^{*} \\
(1.25)\end{array}$ & & $\begin{array}{c}2.45^{* * *} \\
(0.69)\end{array}$ & & $\begin{array}{c}2.23^{* * *} \\
(0.50)\end{array}$ \\
\hline MHOLDINGD & & $\begin{array}{c}1.84 \\
(1.10)\end{array}$ & & $\begin{array}{l}2.32^{*} \\
(1.24)\end{array}$ & & $\begin{array}{c}2.09 * * * \\
(0.72)\end{array}$ \\
\hline MISSUINGE & & $\begin{array}{c}8.31 \\
(11.66)\end{array}$ & & $\begin{array}{l}-1.20 \\
(2.81)\end{array}$ & & $\begin{array}{c}0.92 \\
(2.74)\end{array}$ \\
\hline MHOLDINGE & & $\begin{array}{c}-2.96^{* *} \\
(1.18)\end{array}$ & & $\begin{array}{c}0.18 \\
(0.74)\end{array}$ & & $\begin{array}{l}-0.34 \\
(0.60)\end{array}$ \\
\hline $99-03$ & & & & & $\begin{array}{l}-0.07^{*} \\
(0.04)\end{array}$ & $\begin{array}{c}-0.07^{*} \\
(0.04)\end{array}$ \\
\hline Constant & $\begin{array}{l}-0.37 \\
(0.37)\end{array}$ & $\begin{array}{c}0.58 \\
(0.36)\end{array}$ & $\begin{array}{l}-0.03 \\
(0.51)\end{array}$ & $\begin{array}{l}0.86^{*} \\
(0.44)\end{array}$ & $\begin{array}{l}-0.22 \\
(0.30)\end{array}$ & $\begin{array}{c}0.39 \\
(0.27)\end{array}$ \\
\hline Obs & 41 & 40 & 46 & 44 & 87 & 84 \\
\hline $\mathrm{R}$ squared & 0.44 & 0.66 & 0.46 & 0.76 & 0.42 & 0.64 \\
\hline
\end{tabular}

Robust standard errors in parenthesis. ${ }^{* * *},{ }^{* *},{ }^{*}$ denote significance at 1,5 and 10 percent levels respectively. $C R E D I T_{0}$ is the initial credit/GDP ratio, $\log ($ GDPpc) is log GDP per capita, SFOREIGN is the share of foreign banks in total bank assets, FX is a dummy for the FX regime, NOECD is a dummy for non-OECD countries, $\mathrm{CAB}$ is the current account balance, MISSUINGD is net debt flows of the money-issuing sectors, MHOLDINGD is net debt flows of the money-holding sectors, MISSUINGE is net equity flows of the money-issuing sectors, MHOLDINGE is net equity flows of the money-holding sectors, 99-03 is a dummy for the 1999-2003 period. 
Table 10: Money regressions

\begin{tabular}{|c|c|c|c|c|c|c|}
\hline & 99-03 & 99-03 & "03-07 & "03-07 & Pooled & Pooled \\
\hline$M O N E Y_{0}$ & $\begin{array}{c}0.03 \\
(0.04)\end{array}$ & $\begin{array}{l}0.07^{*} \\
(0.04)\end{array}$ & $\begin{array}{l}-0.00 \\
(0.07)\end{array}$ & $\begin{array}{c}0.03 \\
(0.08)\end{array}$ & $\begin{array}{c}0.01 \\
(0.07)\end{array}$ & $\begin{array}{c}0.04 \\
(0.06)\end{array}$ \\
\hline $\log (\mathrm{GDPpc})$ & $\begin{array}{c}0.04 \\
(0.02)\end{array}$ & $\begin{array}{c}0.04 \\
(0.03)\end{array}$ & $\begin{array}{c}0.08^{* *} \\
(0.04)\end{array}$ & $\begin{array}{l}-0.01 \\
(0.04)\end{array}$ & $\begin{array}{c}0.06^{* *} \\
(0.03)\end{array}$ & $\begin{array}{l}-0.01 \\
(0.03)\end{array}$ \\
\hline SFOREIGN & $\begin{array}{l}-0.11 \\
(0.08)\end{array}$ & $\begin{array}{l}-0.11 \\
(0.08)\end{array}$ & $\begin{array}{c}0.03 \\
(0.06)\end{array}$ & $\begin{array}{c}0.04 \\
(0.06)\end{array}$ & $\begin{array}{l}-0.00 \\
(0.05)\end{array}$ & $\begin{array}{c}0.03 \\
(0.05)\end{array}$ \\
\hline FX & $\begin{array}{l}-0.01 \\
(0.03)\end{array}$ & $\begin{array}{l}-0.02 \\
(0.03)\end{array}$ & $\begin{array}{c}0.04 \\
(0.05)\end{array}$ & $\begin{array}{l}0.09^{*} \\
(0.05)\end{array}$ & $\begin{array}{c}0.03 \\
(0.03)\end{array}$ & $\begin{array}{l}0.07^{*} \\
(0.04)\end{array}$ \\
\hline NOECD & $\begin{array}{l}-0.07 \\
(0.05)\end{array}$ & $\begin{array}{l}-0.06 \\
(0.05)\end{array}$ & $\begin{array}{l}0.19^{*} \\
(0.11)\end{array}$ & $\begin{array}{c}0.02 \\
(0.10)\end{array}$ & $\begin{array}{c}0.08 \\
(0.07)\end{array}$ & $\begin{array}{l}-0.01 \\
(0.06)\end{array}$ \\
\hline $\mathrm{CAB}$ & $\begin{array}{c}-0.89^{* * * *} \\
(0.29)\end{array}$ & & $\begin{array}{c}-0.93^{* * *} \\
(0.31)\end{array}$ & & $\begin{array}{c}-0.79^{* * *} \\
(0.27)\end{array}$ & \\
\hline MISSUINGD & & $\begin{array}{c}0.03 \\
(0.37)\end{array}$ & & $\begin{array}{l}-0.17 \\
(0.60)\end{array}$ & & $\begin{array}{c}0.02 \\
(0.32)\end{array}$ \\
\hline MHOLDINGD & & $\begin{array}{l}1.22^{* *} \\
(0.45)\end{array}$ & & $\begin{array}{l}1.81^{* *} \\
(0.86)\end{array}$ & & $\begin{array}{c}1.40^{* * * *} \\
(0.52)\end{array}$ \\
\hline MISSUINGE & & $\begin{array}{c}2.82 \\
(3.75)\end{array}$ & & $\begin{array}{l}-1.25 \\
(2.18)\end{array}$ & & $\begin{array}{l}-0.36 \\
(1.78)\end{array}$ \\
\hline MHOLDINGE & & $\begin{array}{c}0.74 \\
(0.57)\end{array}$ & & $\begin{array}{l}-1.39 \\
(0.91)\end{array}$ & & $\begin{array}{l}-1.15^{*} \\
(0.68)\end{array}$ \\
\hline 99-03 & & & & & $\begin{array}{c}0.01 \\
(0.02)\end{array}$ & $\begin{array}{c}0.01 \\
(0.02)\end{array}$ \\
\hline Constant & $\begin{array}{l}-0.21 \\
(0.22)\end{array}$ & $\begin{array}{l}-0.26 \\
(0.24)\end{array}$ & $\begin{array}{l}-0.77^{*} \\
(0.40)\end{array}$ & $\begin{array}{c}0.12 \\
(0.40)\end{array}$ & $\begin{array}{l}-0.49^{*} \\
(0.29)\end{array}$ & $\begin{array}{c}0.09 \\
(0.24)\end{array}$ \\
\hline Obs & 29 & 28 & 45 & 43 & 74 & 71 \\
\hline $\mathrm{R}$ squared & 0.64 & 0.67 & 0.25 & 0.43 & 0.23 & 0.40 \\
\hline
\end{tabular}

Robust standard errors in parenthesis. ${ }^{* * *},{ }^{* *},{ }^{*}$ denote significance at 1,5 and 10 percent levels respectively. $M O N E Y_{0}$ is the initial money/GDP ratio, $\log (\mathrm{GDPpc})$ is $\log$ GDP per capita, SFOREIGN is the share of foreign banks in total bank assets, FX is a dummy for the FX regime, NOECD is a dummy for non-OECD countries, $\mathrm{CAB}$ is the current account balance, MISSUINGD is net debt flows of the money-issuing sectors, MHOLDINGD is net debt flows of the money-holding sectors, MISSUINGE is net equity flows of the money-issuing sectors, MHOLDINGE is net equity flows of the money-holding sectors, 99-03 is a dummy for the 1999-2003 period. 
Table 11: Credit to money ratio regressions

\begin{tabular}{|c|c|c|c|c|c|c|}
\hline & $\begin{array}{l}99-03 \\
\end{array}$ & $99-03$ & $03-07$ & 03-07 & Pooled & Pooled \\
\hline$C R E D I T / M O N E Y_{0}$ & $\begin{array}{c}0.07 \\
(0.21)\end{array}$ & $\begin{array}{l}-0.01 \\
(0.20)\end{array}$ & $\begin{array}{c}0.08 \\
(0.06)\end{array}$ & $\begin{array}{l}-0.02 \\
(0.09)\end{array}$ & $\begin{array}{c}0.06 \\
(0.05)\end{array}$ & $\begin{array}{c}-0.01 \\
(0.07)\end{array}$ \\
\hline $\log ($ GDPpc $)$ & $\begin{array}{l}-0.02 \\
(0.07)\end{array}$ & $\begin{array}{l}-0.07 \\
(0.06)\end{array}$ & $\begin{array}{c}-0.09^{*} \\
(0.05)\end{array}$ & $\begin{array}{l}-0.07 \\
(0.08)\end{array}$ & $\begin{array}{c}-0.07^{*} \\
(0.04)\end{array}$ & $\begin{array}{c}-0.07 \\
(0.05)\end{array}$ \\
\hline SFOREIGN & $\begin{array}{l}-0.22 \\
(0.25)\end{array}$ & $\begin{array}{l}-0.17 \\
(0.23)\end{array}$ & $\begin{array}{c}0.04 \\
(0.09)\end{array}$ & $\begin{array}{c}0.02 \\
(0.09)\end{array}$ & $\begin{array}{l}-0.00 \\
(0.07)\end{array}$ & $\begin{array}{c}-0.01 \\
(0.07)\end{array}$ \\
\hline FXFIXED & $\begin{array}{c}0.03 \\
(0.07)\end{array}$ & $\begin{array}{c}0.06 \\
(0.09)\end{array}$ & $\begin{array}{l}-0.00 \\
(0.07)\end{array}$ & $\begin{array}{c}0.01 \\
(0.07)\end{array}$ & $\begin{array}{c}0.02 \\
(0.05)\end{array}$ & $\begin{array}{c}0.03 \\
(0.06)\end{array}$ \\
\hline NOECD & $\begin{array}{l}-0.24^{*} \\
(0.13)\end{array}$ & $\begin{array}{l}-0.24^{*} \\
(0.14)\end{array}$ & $\begin{array}{c}-0.22^{*} \\
(0.11)\end{array}$ & $\begin{array}{l}-0.14 \\
(0.18)\end{array}$ & $\begin{array}{c}-0.24^{* * *} \\
(0.08)\end{array}$ & $\begin{array}{c}-0.23^{* *} \\
(0.11)\end{array}$ \\
\hline $\mathrm{CAB}$ & $\begin{array}{l}-1.15 \\
(0.92)\end{array}$ & & $\begin{array}{c}-1.74^{* * * *} \\
(0.55)\end{array}$ & & $\begin{array}{c}-1.40 * * * \\
(0.50)\end{array}$ & \\
\hline MISSUINGD & & $\begin{array}{c}2.81^{* *} \\
(1.33)\end{array}$ & & $\begin{array}{c}2.87^{* * *} \\
(1.05)\end{array}$ & & $\begin{array}{c}1.97^{* *} \\
(0.84)\end{array}$ \\
\hline MHOLDINGD & & $\begin{array}{c}2.20 \\
(1.87)\end{array}$ & & $\begin{array}{l}-0.48 \\
(1.01)\end{array}$ & & $\begin{array}{c}0.62 \\
(1.02)\end{array}$ \\
\hline MISSUINGE & & $\begin{array}{c}-0.91 \\
(14.01)\end{array}$ & & $\begin{array}{c}1.84 \\
(4.11)\end{array}$ & & $\begin{array}{c}2.19 \\
(4.72)\end{array}$ \\
\hline MHOLDINGE & & $\begin{array}{l}-1.31 \\
(1.41)\end{array}$ & & $\begin{array}{l}2.13^{*} \\
(1.06)\end{array}$ & & $\begin{array}{c}1.10 \\
(0.77)\end{array}$ \\
\hline 99-03 & & & & & $\begin{array}{l}-0.07 \\
(0.05)\end{array}$ & $\begin{array}{c}-0.10^{*} \\
(0.06)\end{array}$ \\
\hline Constant & $\begin{array}{c}0.27^{*} \\
(0.43) \\
\end{array}$ & $\begin{array}{l}0.80^{*} \\
(0.46) \\
\end{array}$ & $\begin{array}{l}0.91^{*} \\
(0.52)\end{array}$ & $\begin{array}{c}0.80 \\
(0.82) \\
\end{array}$ & $\begin{array}{c}0.69 \\
(0.36) \\
\end{array}$ & $\begin{array}{l}0.81^{*} \\
(0.45)\end{array}$ \\
\hline Obs & 29 & 28 & 44 & 42 & 73 & 70 \\
\hline R squared & 0.48 & 0.57 & 0.45 & 0.51 & 0.43 & 0.44 \\
\hline
\end{tabular}

Robust standard errors in parenthesis. ***,**,* denote significance at 1, 5 and 10 percent levels respectively. $C R E D I T / M O N E Y_{0}$ is the initial credit/money ratio, $\log (\mathrm{GDPpc})$ is log GDP per capita, SFOREIGN is the share of foreign banks in total bank assets, FX is a dummy for the FX regime, NOECD is a dummy for nonOECD countries, CAB is the current account balance, MISSUINGD is net debt flows of the money-issuing sectors, MHOLDINGD is net debt flows of the moneyholding sectors, MISSUINGE is net equity flows of the money-issuing sectors, MHOLDINGE is net equity flows of the money-holding sectors, 99-03 is a dummy for the 1999-2003 period. 
Table 12: Credit to money ratio regressions - alternative flow specification

\begin{tabular}{|c|c|c|c|c|c|c|}
\hline & 99-03 & 99-03 & 03-07 & 203-07 & Pooled & Pooled \\
\hline CREDIT/MONEY & $\begin{array}{c}0.07 \\
(0.21)\end{array}$ & $\begin{array}{l}-0.06 \\
(0.24)\end{array}$ & $\begin{array}{c}0.08 \\
(0.06)\end{array}$ & $\begin{array}{c}0.02 \\
(0.08)\end{array}$ & $\begin{array}{c}0.06 \\
(0.05)\end{array}$ & $\begin{array}{l}-0.00 \\
(0.07)\end{array}$ \\
\hline $\log (\mathrm{GDPpc})$ & $\begin{array}{l}-0.02 \\
(0.07)\end{array}$ & $\begin{array}{l}-0.05 \\
(0.08)\end{array}$ & $\begin{array}{l}-0.09^{*} \\
(0.05)\end{array}$ & $\begin{array}{l}-0.07 \\
(0.07)\end{array}$ & $\begin{array}{l}-0.07^{*} \\
(0.04)\end{array}$ & $\begin{array}{l}-0.06 \\
(0.04)\end{array}$ \\
\hline SFOREIGN & $\begin{array}{l}-0.22 \\
(0.26)\end{array}$ & $\begin{array}{l}-0.18 \\
(0.26)\end{array}$ & $\begin{array}{c}0.04 \\
(0.09)\end{array}$ & $\begin{array}{c}0.03 \\
(0.09)\end{array}$ & $\begin{array}{l}-0.00 \\
(0.07)\end{array}$ & $\begin{array}{l}-0.02 \\
(0.07)\end{array}$ \\
\hline FX & $\begin{array}{c}0.03 \\
(0.07)\end{array}$ & $\begin{array}{c}0.05 \\
(0.10)\end{array}$ & $\begin{array}{l}-0.00 \\
(0.07)\end{array}$ & $\begin{array}{l}-0.01 \\
(0.07)\end{array}$ & $\begin{array}{c}0.02 \\
(0.05)\end{array}$ & $\begin{array}{c}0.03 \\
(0.06)\end{array}$ \\
\hline NOECD & $\begin{array}{l}-0.24^{*} \\
(0.13)\end{array}$ & $\begin{array}{l}-0.21 \\
(0.15)\end{array}$ & $\begin{array}{c}-0.22^{*} \\
(0.11)\end{array}$ & $\begin{array}{l}-0.12 \\
(0.17)\end{array}$ & $\begin{array}{c}-0.24^{* * *} \\
(0.08)\end{array}$ & $\begin{array}{c}-0.22^{* *} \\
(0.11)\end{array}$ \\
\hline $\mathrm{CAB}$ & $\begin{array}{l}-1.15 \\
(0.92)\end{array}$ & & $\begin{array}{c}-1.74^{* * *} \\
(0.55)\end{array}$ & & $\begin{array}{c}-1.40^{* * *} \\
(0.50)\end{array}$ & \\
\hline MISSUINGD & & $\begin{array}{c}2.77^{* *} \\
(1.37)\end{array}$ & & $\begin{array}{c}3.34^{* * * *} \\
(0.96)\end{array}$ & & $\begin{array}{c}2.32^{* * * *} \\
(0.87)\end{array}$ \\
\hline MHOLDINGD & & $\begin{array}{c}1.66 \\
(1.75)\end{array}$ & & $\begin{array}{l}-0.17 \\
(0.63)\end{array}$ & & $\begin{array}{c}0.36 \\
(0.73)\end{array}$ \\
\hline MISSUINGE & & $\begin{array}{c}-3.73 \\
(14.31)\end{array}$ & & $\begin{array}{c}2.18 \\
(3.09)\end{array}$ & & $\begin{array}{c}2.23 \\
(3.80)\end{array}$ \\
\hline MHOLDINGE & & $\begin{array}{l}-0.74 \\
(1.67)\end{array}$ & & $\begin{array}{c}3.07^{* * *} \\
(1.01)\end{array}$ & & $\begin{array}{l}1.73^{*} \\
(0.91)\end{array}$ \\
\hline 99-03 & & & & & $\begin{array}{l}-0.07 \\
(0.05)\end{array}$ & $\begin{array}{l}-0.11^{*} \\
(0.06)\end{array}$ \\
\hline Constant & $\begin{array}{c}0.27 \\
(0.43)\end{array}$ & $\begin{array}{c}0.58 \\
(0.49)\end{array}$ & $\begin{array}{l}0.91^{*} \\
(0.52)\end{array}$ & $\begin{array}{c}0.72 \\
(0.73)\end{array}$ & $\begin{array}{l}-0.69^{*} \\
(0.36)\end{array}$ & $\begin{array}{l}0.74^{*} \\
(0.43)\end{array}$ \\
\hline Obs & 29 & 28 & 44 & 42 & 73 & 70 \\
\hline $\mathrm{R}$ squared & 0.48 & 0.52 & 0.45 & 0.54 & 0.43 & 0.45 \\
\hline
\end{tabular}

Robust standard errors in parenthesis. ${ }^{* * *},{ }^{* *},{ }^{*}$ denote significance at 1,5 and 10 percent levels respectively. $C R E D I T / M O N E Y_{0}$ is the initial credit/money ratio, $\log (\mathrm{GDPpc})$ is log GDP per capita, SFOREIGN is the share of foreign banks in total bank assets, FX is a dummy for the FX regime, NOECD is a dummy for nonOECD countries, CAB is the current account balance, MISSUINGD is net debt flows of the money-issuing sectors, MHOLDINGD is net debt flows of the moneyholding sectors, MISSUINGE is net equity flows of the money-issuing sectors, MHOLDINGE is net equity flows of the money-holding sectors, 99-03 is a dummy for the 1999-2003 period. 



\section{WORKING PAPERS}

\section{2}

1|12 Public-private wage gaps in the period prior to the adoption of the euro: An application based on longitudinal data

Maria Manuel Campos | Mário Centeno

2|12 Asset pricing with a bank risk factor João Pedro Pereira | António Rua

3|12 A wavelet-based assessment of market risk: The emerging markets case

António Rua | Luis C. Nunes

4|12 Cohesion within the euro area and the $U$.

S.: A wavelet-based view

António Rua | Artur Silva Lopes

5|12 Excess worker turnover and fixed-term contracts: Causal evidence in a two-tier system

Mário Centeno | Álvaro A. Novo

6|12 The dynamics of capital structure decisions

Paula Antão | Diana Bonfim

7|12 Quantile regression for long memory testing: A case of realized volatility

Uwe Hassler | Paulo M. M. Rodrigues | Antonio Rubia

8|12 Competition in the Portuguese Economy: An overview of classical indicators

João Amador | Ana Cristina Soares

9|12 Market perception of fiscal sustainability: An application to the largest euro area economies

Maximiano Pinheiro
10|12 The effects of public spending externalities Valerio Ercolani | João Valle e Azevedo

11|12 Collateral requirements: Macroeconomic fluctuations and macro-prudential policy Caterina Mendicino

12|12 Wage rigidity and employment adjustment at the firm level: Evidence from survey data

Daniel A. Dias | Carlos Robalo Marques | Fernando Martins

13|12 How to create indices for bank branch financial performance measurement using MCDA techniques: An illustrative example Fernando A. F. Ferreira | Paulo M. M. Rodrigues | Sérgio P. Santos | Ronald W. Spahr

14|12 On International policy coordination and the correction of global imbalances Bruno Albuquerque | Cristina Manteu

15|12 Identifying the determinants of downward wage rigidity: some methodological considerations and new empirical evidence Daniel A. Dias | Carlos Robalo Marques | Fernando Martins

16|12 Systemic risk analysis using forward-looking distance-to-default series

Martín Saldías

17|12 Competition in the Portuguese Economy: Insights from a profit elasticity approach João Amador | Ana Cristina Soares

18|12 Liquidity risk in banking: Is there herding? Diana Bonfim | Moshe Kim 
19|12 Bank size and lending specialization Diana Bonfim | Qinglei Dai

\section{3}

01|13 Macroeconomic forecasting using lowfrequency filters

João Valle | Azevedo, Ana Pereira

02|13 Everything you always wanted to know about sex discrimination

Ana Rute Cardoso | Paulo Guimarães |

Pedro Portugal

$03 \mid 13$ Is there a role for domestic demand pressure on export performance?

Paulo Soares Esteves | António Rua

04|13 Ageing and fiscal sustainability in a small euro area economy

Gabriela Castro | José R. Maria | Ricardo Mourinho Félix | Cláudia Rodrigues Braz

05|13 Mind the gap! The relative wages of immigrants in the Portuguese labour market Sónia Cabral | Cláudia Duarte

06|13 Foreign direct investment and institutional reform: Evidence and an application to Portugal

Paulo Júlio | Ricardo Pinheiro-Alves | José Tavares

07|13 Monetary policy shocks: We got news! Sandra Gomes | Nikolay Iskrev | Caterina Mendicino

08|13 Competition in the Portuguese Economy: Estimated price-cost margins under imperfect labour markets

João Amador | Ana Cristina Soares

$09 \mid 13$ The sources of wage variation: a threeway high-dimensional fixed effects regression model
Sonia Torres | Pedro Portugal | John T. Addison | Paulo Guimarães

10|13 The output effects of (non-separable) government consumption at the zero lower bound

Valerio Ercolani | João Valle e Azevedo

11|13 Fiscal multipliers in a small euro area economy: How big can they get in crisis times?

Gabriela Castro | Ricardo M. Felix | Paulo Julio | Jose R. Maria

12|13 Survey evidence on price and wage rigidities in Portugal

Fernando Martins

13|13 Characterizing economic growth paths based on new structural change tests

Nuno Sobreira | Luis C. Nunes | Paulo M. M. Rodrigues

14|13 Catastrophic job destruction Anabela Carneiro | Pedro Portugal | José Varejão

15|13 Output effects of a measure of tax shocks based on changes in legislation for Portugal

Manuel Coutinho Pereira | Lara Wemans

16|13 Inside PESSOA - A detailed description of the model

Vanda Almeida | Gabriela Castro | Ricardo M. Félix | Paulo Júlio | José R. Maria

17|13 Macroprudential regulation and macroeconomic activity

Sudipto Karmakar

18|13 Bank capital and lending: An analysis of commercial banks in the United States Sudipto Karmakar | Junghwan Mok 


\section{4}

1|14 Autoregressive augmentation of MIDAS regressions

Cláudia Duarte

2|14 The risk-taking channel of monetary policy - exploring all avenues

Diana Bonfim | Carla Soares

3|14 Global value chains: Surveying drivers, measures and impacts

João Amador | Sónia Cabral

4|14 Has US household deleveraging ended? a model-based estimate of equilibrium debt

Bruno Albuquerque | Ursel Baumann | Georgi Krustev

5|14 The weather effect: Estimating the effect of voter turnout on electoral outcomes in Italy

Alessandro Sforza

6|14 Persistence in the Banking Industry: Fractional integration and breaks in memory

Uwe Hassler, Paulo M.M. Rodrigues, Antonio Rubia

7|14 Financial integration and the Great Leveraging

Daniel Carvalho 



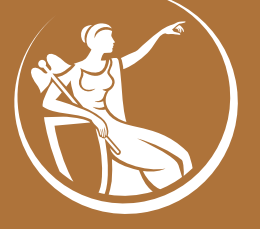

